\title{
Effect of ligand modification on hydrogen production catalyzed by iron(III) complexes supported by amine-bis(phenolate) ligands
}

\author{
Ling-Zhi Tang, Chen-Neng Lin, Shu-Zhong Zhan* \\ College of Chemistry and Chemical Engineering, South China University of Technology, \\ Guangzhou 510640, China.
}

\begin{abstract}
In the presence of trimethylamine, the reaction of $\mathrm{FeCl}_{3}$ with 2-pyridylamino-N,N-bis(2-methylene-4-methyl-6-tert-butylphenol) $\quad\left(\mathrm{H}_{2} \mathrm{~L}\right) \quad$ and 2-pyridylamino-N,N-bis(2-methylene-4-methoxyl-6-tert-butylphenol) produces two iron(III) complexes, [LFeCl] (1) and [L'FeCl] (2), respectively. 1 can electrocatalyze hydrogen evolution both from acetic acid, with a turnover frequency (TOF) of 98.5 moles of hydrogen per mole of catalyst per hour at an overpotential (OP) of $941.6 \mathrm{mV}$ (in DMF), and from aqueous buffer solution ( $\mathrm{pH} 7.0$ ), with a TOF of 676.6 moles of hydrogen per mole of catalyst per hour at an OP of $836.6 \mathrm{mV}$. 2 electrocatalyzes hydrogen generation from acetic acid, with a TOF of 50.6 moles of hydrogen per mole of catalyst per hour at an $\mathrm{OP}$ of $941.6 \mathrm{mV}$, and from aqueous buffer solution ( $\mathrm{pH} 7.0$ ), with a TOF of 554 moles of hydrogen per mole of catalyst per hour at an OP of $836.6 \mathrm{mV}$. These results indicate that the electronic properties of the ligands play a vital role in determining the catalytic activities of the iron complexes.
\end{abstract}

Keywords: Iron complexes; molecular structures; electrocatalysts; hydrogen evolution 
* Corresponding author. Fax: +86-20-87112053.

E-mail address: shzhzhan@scut.edu.cn (S.-Z.Zhan).

\section{Introduction}

Increasing energy and environmental concerns have encouraged researchers to explore sustainable and renewable alternatives of conventional fossil fuels, such as hydrogen energy with zero carbon emissions [1]. Water splitting is an ideal method for hydrogen production with high purity and in large quantities [2]. In nature, hydrogenase enzymes are very efficient catalysts for both the reductive generation and oxidative uptake of dihydrogen [3]. However, enzymes are difficult to adapt for commercial applications and their stability is often limited outside of their native environment $[4,5]$. Therefore, effective proton reduction to form $\mathrm{H}_{2}$ has been a subject of intense study and significant effort has been made to design metal complexes for proton reduction [6]. So far, several complexes that contain nickel [7-10], cobalt [11-14], iron [15-18], copper [19-23] and molybdenum [24-26] have been developed as electrocatalysts for the reduction of water to form $\mathrm{H}_{2}$. A number of model complexes have been prepared, but an important fundamental question about the enzymes that remains to be answered is the precise role of the ligands in hydrogen production. With this mind, we are trying to explore the possibility of catalysis for hydrogen evolution from water by transition metal complexes with different ligands, because the donor type and electronic properties of the ligands play vital roles in determining the structure and reactivity of the corresponding metal complexes. In general, iron(III) complexes are used as electrocatalysts for water oxidation [27-29], 
and there are a few reports on water reduction by iron(III) complexes [30]. Herein, we present the synthesis, characterization and electrocatalytic properties for hydrogen evolution from both acetic acid and aqueous buffer of two iron(III) complexes, [LFeCl] (1) and [L'FeCl] (2), as well as the effect of the modification of the tetradentate ligand on the catalytic properties of two iron(III) complexes.

\section{Experimental}

\subsection{Physical measurements}

Elemental analyses for $\mathrm{C}, \mathrm{H}$ and $\mathrm{N}$ were conducted on a Perkin-Elmer analyzer model 240. ESI-MS experiments were performed by introducing samples directly into the ESI source using a syringe pump on a Bruker Daltonics Esquire 3000 spectrometer. Cyclic voltammograms (CVs) were obtained on a CHI-660E electrochemical analyzer under $\mathrm{N}_{2}$ using a three-electrode cell in which a glassy carbon electrode was the working electrode, a saturated $\mathrm{Ag} / \mathrm{AgCl}$ or $\mathrm{Ag} / \mathrm{AgNO}_{3}$ electrode was the reference electrode and a platinum wire was the auxiliary electrode. In organic media, the ferrocene/ferrocenium (1+) couple was used as an internal standard and 0.10 $\mathrm{M}\left[(\mathrm{n}-\mathrm{Bu})_{4} \mathrm{~N}\right] \mathrm{ClO}_{4}$ was used as the supporting electrolyte. Controlled-potential electrolysis (CPE) was conducted using an air-tight glass double compartment cell separated by a glass frit. The working compartment was fitted with a glassy carbon plate and an $\mathrm{Ag} / \mathrm{AgNO}_{3}$ (organic medium) or $\mathrm{Ag} / \mathrm{AgCl}$ (aqueous medium) reference electrode. The auxiliary compartment was fitted with a Pt gauze electrode. The working compartment was charged with $50 \mathrm{~mL}$ of $0.10 \mathrm{M}$ 
$\left[(\mathrm{n}-\mathrm{Bu})_{4} \mathrm{~N}\right] \mathrm{ClO}_{4} \mathrm{DMF}$ solution (organic medium) or $0.25 \mathrm{M}$ phosphate buffer solution (aqueous medium) containing the iron complex, while the auxiliary compartment contained $35 \mathrm{~mL}$ of $0.10 \mathrm{M}\left[(\mathrm{n}-\mathrm{Bu})_{4} \mathrm{~N}\right] \mathrm{ClO}_{4} \mathrm{DMF}$ solution (organic medium) or $0.25 \mathrm{M}$ phosphate buffer solution (aqueous medium). After electrolysis, a $0.5 \mathrm{~mL}$ aliquot of the headspace was removed and replaced with $0.5 \mathrm{~mL}$ of $\mathrm{CH}_{4}$. The headspace sample was injected into the gas chromatograph (GC). GC experiments were carried out with an Agilent Technologies 7890A gas chromatography instrument.

\subsection{Synthesis of 2-pyridylamino-N,N-bis(2-methylene-4-methyl-6-tert-butylphenol)} $\left(H_{2} L\right)$

A solution of 2-tert-butyl-4-methylphenol (3.28 g, $20 \mathrm{mmol})$, aminomethylpyridine (1.08 g, $10 \mathrm{mmol})$ and 37\% aqueous formaldehyde (1.62 g, 20 mmol) in water $(50 \mathrm{~mL})$ was stirred and refluxed for $8 \mathrm{~h}$. Upon cooling, a large quantity of beige solid formed. The solvents were decanted and the remaining solid residue was washed with cold methanol to give a pure white powder $(3.65 \mathrm{~g}, 79 \%)$. A crystalline product was obtained by slow cooling of a hot diethyl ether solution. Anal. calcd for $\mathrm{C}_{30} \mathrm{H}_{40} \mathrm{~N}_{2} \mathrm{O}_{2}: C, 78.26 ; \mathrm{H}, 8.70 ; \mathrm{N}, 4.38 \%$. Found $\mathrm{C}, 78.31 ; \mathrm{H}, 8.80 ; \mathrm{N}$, 4.38\%. ${ }^{1} \mathrm{H}$ NMR (400 MHz, $\left.\mathrm{CDCl}_{3}\right) \delta$, ppm: 10.38 (s, 2H), $8.60(\mathrm{~d}, J=4.8 \mathrm{~Hz}, 1 \mathrm{H})$, $7.60(\mathrm{td}, J=7.7,1.4 \mathrm{~Hz}, 1 \mathrm{H}), 7.18(\mathrm{dd}, J=12.7,5.5 \mathrm{~Hz}, 1 \mathrm{H}), 7.02(\mathrm{~d}, J=7.8 \mathrm{~Hz}$, 1H), $6.92(\mathrm{~d}, J=1.2 \mathrm{~Hz}, 2 \mathrm{H}), 6.66(\mathrm{~s}, 2 \mathrm{H}), 3.73(\mathrm{~s}, 2 \mathrm{H}), 3.67(\mathrm{~s}, 4 \mathrm{H}), 2.16(\mathrm{~s}, 6 \mathrm{H})$, $1.31(\mathrm{~s}, 18 \mathrm{H}) .{ }^{13} \mathrm{C} \mathrm{NMR}\left(101 \mathrm{MHz}, \mathrm{CDCl}_{3}\right) \delta, \mathrm{ppm}: 155.06$ (s), $152.86(\mathrm{~s}), 147.09$ (s), 
136.30 (s), 136.06 (s), 127.91 (s), 126.04 (d, $J=13.6 \mathrm{~Hz}), 122.60$ (s), 121.44 (s), 121.05 (s), 76.29 (s), 75.97 (s), 75.66 (s), 55.18 (s), 54.26 (s), 33.73 (s), 28.55 (s), $19.70(\mathrm{~s})$.

2.3. Synthesis of 2-pyridylamino-N,N-bis(2-methylene-4-methoxyl-6-tert-butylphenol) $\left(H_{2} L^{\prime}\right)$.

The procedure was performed in the same way as that for the synthesis of $\mathrm{H}_{2} \mathrm{~L}$ except that 2-tert-butyl-4-methylphenol was replaced by 2-tert-butyl-4-methoxylphenol. $\mathrm{H}_{2} \mathrm{~L}^{\prime}$ was obtained in a yield of $75 \%$ (3.69 g). Anal. calcd for $\mathrm{C}_{30} \mathrm{H}_{40} \mathrm{~N}_{2} \mathrm{O}_{4}: \mathrm{C}, 73.17 ; \mathrm{H}, 8.13 ; \mathrm{N}, 5.69 \%$. Found $\mathrm{C}, 73.31 ; \mathrm{H}, 8.13 ; \mathrm{N}$, 5.70\%. ${ }^{1} \mathrm{H}$ NMR (400 MHz, $\left.\mathrm{CDCl}_{3}\right) \delta, \mathrm{ppm}: 10.29(\mathrm{~s}, 2 \mathrm{H}), 8.68(\mathrm{~d}, J=4.6 \mathrm{~Hz}, 1 \mathrm{H})$, $7.69(\mathrm{dd}, J=10.9,4.3 \mathrm{~Hz}, 1 \mathrm{H}), 7.26(\mathrm{dd}, J=14.6,7.7 \mathrm{~Hz}, 1 \mathrm{H}), 7.11(\mathrm{~d}, J=7.8 \mathrm{~Hz}$, $1 \mathrm{H}), 6.83(\mathrm{~d}, J=2.9 \mathrm{~Hz}, 2 \mathrm{H}), 6.51(\mathrm{~d}, J=2.8 \mathrm{~Hz}, 2 \mathrm{H}), 3.76(\mathrm{~d}, J=13.6 \mathrm{~Hz}, 11 \mathrm{H})$, 1.40 (s, 17H). ${ }^{13} \mathrm{C}$ NMR (101 MHz, $\left.\mathrm{CDCl}_{3}\right) \delta$, ppm: 155.84 (s), 151.81 (s), 150.20 (s), 148.18 (s), 138.86 (s), 137.49 (s), 123.95 (s), 122.64 (s), 113.55 (s), 112.40 (s), 77.39 (s), 77.07 (s), 76.75 (s), 56.29 (s), 55.72 (s), 55.00 (s), 35.08 (s), 29.50 (s).

\subsection{Synthesis of complex [ $\mathrm{LFeCl}](\mathbf{1})$}

To a solution, containing $\mathrm{H}_{2} \mathrm{~L}(0.46 \mathrm{~g}, 1.0 \mathrm{mmol})$ and triethylamine $(0.20 \mathrm{~g}$, $2.0 \mathrm{mmol})$ in THF $(20 \mathrm{ml}), \mathrm{FeCl}_{3}(0.162 \mathrm{~g}, 1.0 \mathrm{mmol})$ in methanol was added and the mixture was stirred for 15 min. Single crystals were obtained from the filtrate, after standing at room temperature for several days, and these were collected by filtration, 
and dried in vacuo $(0.41 \mathrm{~g}, 75 \%)$. The elemental analysis results (Found: C 65.18; H 6.92; $\mathrm{N}$ 5.03\%; $\mathrm{C}_{30} \mathrm{H}_{38} \mathrm{~N}_{2} \mathrm{O}_{2} \mathrm{FeCl}$ requires: $\mathrm{C} 65.46 ; \mathrm{H} 6.91 ; \mathrm{N} \mathrm{5.09 \% )} \mathrm{are} \mathrm{in}$ agreement with the formula of the sample used for X-ray analysis.

\subsection{Synthesis of complex [L'FeCl] (2)}

The procedure was performed in the same way as that for the synthesis of $\mathbf{1}$ except that $\mathrm{H}_{2} \mathrm{~L}$ was replaced by $\mathrm{H}_{2} \mathrm{~L}^{\prime}$. Complex 2 was obtained in a yield of $71 \%(0.42 \mathrm{~g})$. The elemental analysis results (Found: $\mathrm{C} 61.12 ; \mathrm{H} 6.52 ; \mathrm{N} 4.81 \% ; \mathrm{C}_{30} \mathrm{H}_{38} \mathrm{~N}_{2} \mathrm{O}_{4} \mathrm{FeCl}$ requires: $\mathrm{C} 61.86 ; \mathrm{H} 6.53 ; \mathrm{N} 4.81 \%$ ) are in agreement with the formula of the sample used for X-ray analysis.

\subsection{Crystal structure determination}

X-ray analyses of complexes $\mathbf{1}$ and $\mathbf{2}$ were carried out with a Bruker Smart Apex II DUO area detector using graphite monochromated Mo-K $\alpha$ radiation $(\lambda=0.71073 \AA)$ at room temperature. All empirical absorption corrections were applied by using the SADABS program [31]. The structures were solved using direct methods and the corresponding non-hydrogen atoms were refined anisotropically. All the hydrogen atoms of the ligands were placed in calculated positions with fixed isotropic thermal parameters and included in the structure factor calculations in the final stage of full-matrix least-squares refinement. All calculations were performed using the SHELXTL-97 computer program [32]. Crystallographic data for complexes 1 and $\mathbf{2}$ are given in Tables S1-S2 and selected bond lengths are listed in Tables S3-S4. 


\section{Results and discussion}

\subsection{Structures and general characterization}

In the presence of triethylamine, the reaction of $\mathrm{FeCl}_{3}$ with $\mathrm{H}_{2} \mathrm{~L}$ and $\mathrm{H}_{2} \mathrm{~L}$ ' (Figs. S1-S2) affords two iron(III) complexes, [LFeCl] (1) and [L'FeCl] (2), in 75 and $71 \%$ yields, respectively (Scheme 1).

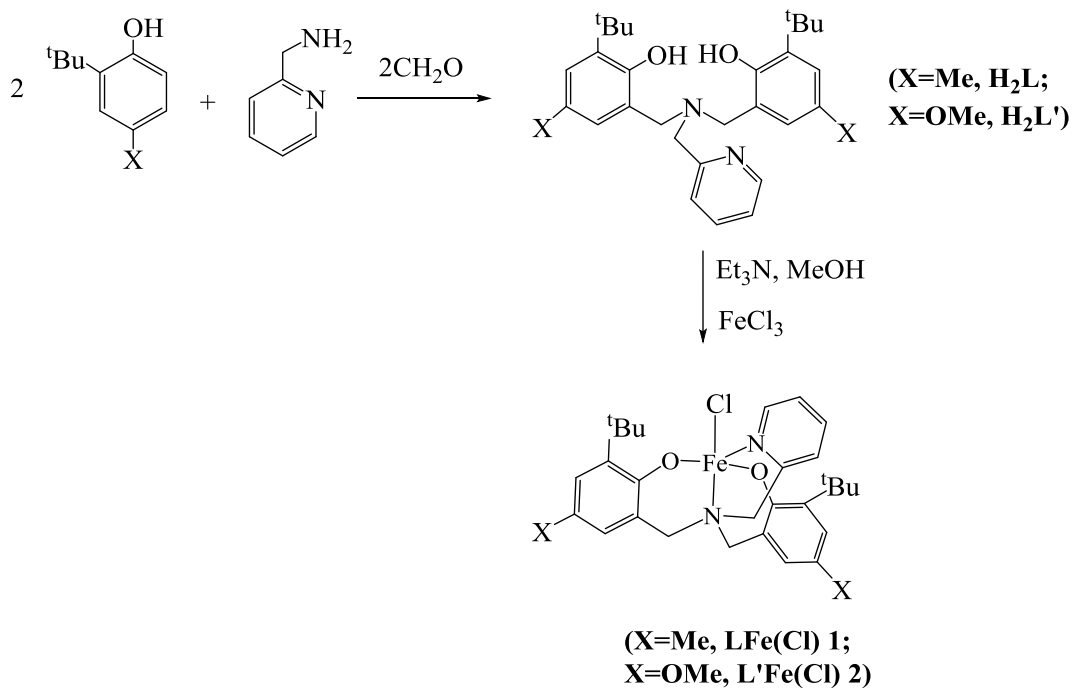

Scheme 1 The synthesis of $[\mathrm{LFe}(\mathrm{Cl})] \mathbf{1}$ and [ $\mathrm{L}^{\prime} \mathrm{Fe}(\mathrm{Cl}) \mathbf{2}$.

The electronic spectra of $\mathrm{H}_{2} \mathrm{~L}, \mathrm{H}_{2} \mathrm{~L}, \mathbf{1}$ and 2 were recorded in $\mathrm{CH}_{3} \mathrm{CN}$ at room temperature. As shown in Figs. S3-S4, $\mathrm{H}_{2} \mathrm{~L}$ and $\mathrm{H}_{2} \mathrm{~L}$ ' each exhibit one band at 283 and $296 \mathrm{~nm}$, respectively. Compared with that of $\mathrm{H}_{2} \mathrm{~L}$, two new absorption bands appeared at 335 and $506 \mathrm{~nm}$ for $\mathbf{1}$. The lower energy band can be assigned to a phenolate $\mathrm{p}_{\pi}$ to $\mathrm{Fe}^{\mathrm{III}} \mathrm{d}_{\pi}{ }^{*}$ charge transfer (CT) transition, and the higher energy band is attributed to a phenolate $\mathrm{p}$ to $\mathrm{Fe}^{\mathrm{III}} \mathrm{d} \sigma^{*} \mathrm{CT}[33,34]$. Similar to $\mathbf{1}$, complex $\mathbf{2}$ also shows two bands at 348 and $520 \mathrm{~nm}$, which can be attributed to phenolate to $\mathrm{Fe}^{\mathrm{III}} \mathrm{CT}$ transitions.

As shown in Fig. 1, solid complex 1 consists of one iron ion, one $\mathrm{L}^{2-}$ ligand and 
one chloride ion. The iron ion is five-coordinated by two oxygen atoms, two nitrogen atoms and one chloride ion. Fe-N distances are 2.149(2) and 2.2794(18) $\AA$, and the $\mathrm{Fe}-\mathrm{O}$ distances are $1.8379(16)$ and $1.8574(15) \AA$. The $\mathrm{Fe}-\mathrm{Cl}$ bond distance is 2.2884(7) $\AA$. Note, in methanol, the chloride ion dissociates from iron center, which is in agreement with the results from the ESI-MS measurement, which exhibits one ion at a mass-to-charge ratio $(\mathrm{m} / \mathrm{z})$ of 514.2287 , with the mass and isotope distribution pattern corresponding to that of $[\mathrm{LFe}(\mathrm{III})]^{+}$(calculated $\mathrm{m} / \mathrm{z}$ of 514.42) (Fig. S5).

Solid complex 2 is also formed by one iron ion, one $\mathrm{L}^{2-}$ and one chloride ion. The Fe-N distances are 2.144(7) and 2.262(6) $\AA$, and the Fe-O distances are 1.839(5) and 1.845(4) $\AA$. However, the Fe-Cl bond distance of 2.265(2) $\AA$ is shorter than that of complex 1. Similar to complex 1, in methanol, the chloride ion also dissociates from the iron center, which is in agreement with the results from the ESI-MS measurement, which exhibits one ion at a mass-to-charge ratio $(\mathrm{m} / \mathrm{z})$ of 546.2176, with the mass and isotope distribution pattern corresponding to that of $[\mathrm{Fe}(\mathrm{III})(\mathrm{L})]^{+}$ (calculated $m / z$ of 546.42) (Fig. S6).

\subsection{Electrochemical studies}

To study the electrochemical properties of $\mathbf{1}$ and $\mathbf{2}$, CVs were conducted in DMF with $0.10 \mathrm{M}\left[(\mathrm{n}-\mathrm{Bu})_{4} \mathrm{~N}\right] \mathrm{ClO}_{4}$ as the supporting electrolyte. As observed in Fig. 2, both complexes 1 and 2 exhibit two redox waves: 1, -1.55 and -0.72 V versus $\mathrm{Ag} / \mathrm{AgNO}_{3}$; 2, -1.32 and $-0.36 \mathrm{~V}$ versus $\mathrm{Ag} / \mathrm{AgNO}_{3}$. These are in accord with the trend of the lowest-energy absorption spectra of $\mathbf{1}(506 \mathrm{~nm})$ and $\mathbf{2}(520 \mathrm{~nm})$. As shown in Fig. 2a, 
the $\mathrm{CV}$ of complex $\mathbf{1}$ shows a quasi-reversible redox peak at $-0.72 \mathrm{~V}$ and an irreversible wave at $-1.55 \mathrm{~V}$ versus $\mathrm{Ag} / \mathrm{AgNO}_{3}$, which are assigned to the couples of $\mathrm{Fe}^{\mathrm{III}} / \mathrm{Fe}^{\mathrm{II}}$ and $\mathrm{Fe}^{\mathrm{II}} / \mathrm{Fe}^{\mathrm{I}}$, respectively. Complex 2 shows one $\mathrm{Fe}^{\mathrm{III}} / \mathrm{Fe}^{\mathrm{II}}$ redox couple at $\mathrm{E}_{1 / 2}=-0.36 \mathrm{~V}$ and one irreversible $\mathrm{Fe}^{\mathrm{II}} / \mathrm{Fe}^{\mathrm{I}}$ redox wave at $-1.32 \mathrm{~V}$ versus $\mathrm{Ag} / \mathrm{AgNO}_{3}$. The potential of $\mathrm{Fe}^{\mathrm{III}} / \mathrm{Fe}^{\mathrm{II}}$ is shifted by $360 \mathrm{mV}$ as a result of the substitution of a methyl group on the ligand by a methoxyl group.

From Fig. S7, both current responses of the redox events at $-1.55 \mathrm{~V}$ for complex $\mathbf{1}$ and $-1.32 \mathrm{~V}$ for complex 2 show a linear dependence on the square root of the scan rate, indicative of a diffusion-controlled process, with the electrochemically active species freely diffusing in solution. To investigate the effect of the temperature of medium on the electrochemical behavior of the iron complexes, the CVs were measured at various temperatures. For complex 1, the current strength significantly increased near -0.84 and $-1.60 \mathrm{~V}$ on increasing the temperature from 298 to $333 \mathrm{~K}$ (Fig. S8a). Interestingly, the current strength slightly increased near -0.41 and -1.25 $\mathrm{V}$ on increasing the temperature from 298 to $343 \mathrm{~K}$ for complex 2 (Fig. S8b), indicating the temperature has greater effect on complex $\mathbf{1}$.

\subsection{Catalytic hydrogen evolution from acetic acid in DMF}

From Fig. 3a it can be seen that the catalytic currents near -1.55 and $-0.82 \mathrm{~V}$ increase with increasing acetic acid concentration from 0.0 to $4.98 \mathrm{mM}$. This indicates that hydrogen evolution electrocatalyzed by 1 requires the reduction of $\mathrm{Fe}(\mathrm{III})$ to $\mathrm{Fe}(\mathrm{II}), \mathrm{Fe}(\mathrm{II})$ to $\mathrm{Fe}(\mathrm{I})$ and protonation. Interestingly, when the acetic acid 
concentration is increased from 0.0 to $4.98 \mathrm{mM}$ (Fig. 3b), the onset of the catalytic wave remains almost constant at ca. $-0.56 \mathrm{~V}$. Based on these observations, both the $\mathrm{Fe}^{\mathrm{III}} / \mathrm{Fe}^{\mathrm{II}}$ and $\mathrm{Fe}^{\mathrm{II}} / \mathrm{Fe}^{\mathrm{I}}$ couples are involved in the proton reduction, which is different from a previous report where only the $\mathrm{Fe}^{\mathrm{II}} / \mathrm{Fe}^{\mathrm{I}}$ couple is devoted to proton reduction [35]. Compared to complex 1, the change of catalytic current for complex $\mathbf{2}$ appears at the $\mathrm{Fe}^{\mathrm{II}} / \mathrm{Fe}^{\mathrm{I}}$ couple $\left(-1.32 \mathrm{~V}\right.$ versus $\left.\mathrm{Ag} / \mathrm{AgNO}_{3}\right)$, and the peak current of the $\mathrm{Fe}^{\mathrm{III}} / \mathrm{Fe}^{\mathrm{II}}$ couple remains almost constant with increasing proton concentration.

In order to further assess the catalytic activities of complexes $\mathbf{1}$ and $\mathbf{2}$, their bulk electrolyses were conducted in DMF with acetic acid at variable applied potentials. Figs. $4 \mathrm{a}-\mathrm{b}$ show the total charges of the bulk electrolysis of complexes $\mathbf{1}$ and $\mathbf{2}$ in the presence of acetic acid. When the applied potential is $-1.45 \mathrm{~V}$ versus $\mathrm{Ag} / \mathrm{AgNO}$, the maximum charges reach 107 and $47 \mathrm{mC}$, respectively, during 2 min of electrolysis. A CPE experiment under the same potential without complex $\mathbf{1}$ or complex $\mathbf{2}$ gives a charge of only $10 \mathrm{mC}$ (Fig. 4c), indicating that these two iron complexes do indeed serve as effective hydrogen producers under such conditions. According to Equations (1) [25] and (2) [36], we calculated the TOF for the catalysts as reaching a maximum of 98.5 (complex 1) and 50.6 (complex 2) moles of hydrogen per mole of catalyst per hour at an overpotential of $941.6 \mathrm{mV}$ (Eqs. S1-S2, Table 1 and Fig. S9). Remarkably, complex $\mathbf{1}$ is almost two times more effective than complex $\mathbf{2}$, which is consistent with an evident decrease in the catalytic activity when a weakly activating electron donating group is present at the phenol para-position of the ligand, and 2-pyridylamino-N,N-bis(2-methylene-4-methyl-6-tert-butylphenol) constitutes the 
better active catalyst [37].

$\mathrm{TOF}=\Delta C /\left(\mathrm{F}^{*} n_{1} * n_{2} * t\right)$

Overpotential $=$ Applied potential $-\mathrm{E}^{\odot} \mathrm{HA}$

$$
=\text { Applied potential }-\left(\mathrm{E}^{\odot} \mathrm{H}^{+}-(2.303 R T / F) \mathrm{p} K_{a \mathrm{HA}}\right)
$$

where $\Delta C$ is the charge from the catalyst solution during CPE minus the charge from solution without catalyst during CPE; $\mathrm{F}$ is Faraday's constant, $n_{1}$ is the number of moles of electrons required to generate one mole of $\mathrm{H}_{2}, n_{2}$ is the number of moles of catalyst in solution and $\mathrm{t}$ is the duration of the electrolysis.

Table 1 Catalytic data of complexes $\mathbf{1}$ and $\mathbf{2}$ from acetic acid in DMF

\begin{tabular}{|l|l|l|l|}
\hline Components & ${\text { Charge }(\mathrm{mC})^{\mathrm{a}}}^{\mathrm{a}}$ & TOF $^{\mathrm{b}}$ & Overpotential $(\mathrm{mV})$ \\
\hline Complex $\mathbf{1}$ & 107 & 98.5 & 941.6 \\
\hline Complex $\mathbf{2}$ & 47 & 50.6 & 941.6 \\
\hline
\end{tabular}

a 2 min of electrolysis; ${ }^{b}$ moles of hydrogen per mole of catalyst per hour.

\subsection{Catalytic hydrogen evolution from aqueous buffer}

To study the electrochemical behavior of complex $\mathbf{1}$ in aqueous medium, CVs were measured in $0.25 \mathrm{M}$ buffer at different $\mathrm{pH}$ values. According to Fig. 5a, in the absence of complex 1, a catalytic current is not apparent until a potential of $-1.50 \mathrm{~V}$ versus $\mathrm{Ag} / \mathrm{AgCl}$ is reached. Upon addition of complex $\mathbf{1}$, the onset of the catalytic current is observed at about $-1.22 \mathrm{~V}$ versus $\mathrm{Ag} / \mathrm{AgCl}$, showing that addition of complex 1 can reduce the potential, and the current strength increases significantly with an increasing concentration of complex 1 from 0.21 to $1.00 \mu \mathrm{M}$ (Fig. 5a). From Fig. 5b, the onset of this catalytic current is influenced by the $\mathrm{pH}$ value of the medium, and the applied potential declines with increasing $\mathrm{pH}$, evidencing the involvement of 
a proton in the initial stage of the electrochemical catalysis. Similar to complex $\mathbf{1}$, the current strength also increases with an increasing concentration of complex 2 from 0.21 to $1.05 \mu \mathrm{M}$ (Fig. 6a). Complex 2 shows a $\mathrm{pH}$-dependent peak at $-1.62 \mathrm{~V}$ versus $\mathrm{Ag} / \mathrm{AgCl}$, which is responsible for catalytic water reduction (Fig. 6b).

Table 2 shows catalytic data of complexes $\mathbf{1}$ and $\mathbf{2}$ in aqueous buffer. When the applied potential is $-1.45 \mathrm{~V}$ versus $\mathrm{Ag} / \mathrm{AgCl}$, the maximum charge is only $26 \mathrm{mC}$ for 2 min of electrolysis without complex 1 (Fig. 7a), whilst the charge reaches $817 \mathrm{mC}$ during 2 min of electrolysis in the presence of $\mathbf{1}$ (Fig. 7b), accompanied by a large amount of gas bubbles, which were confirmed as $\mathrm{H}_{2}$ by GC. From Fig. S10a, $\sim 636$ $\mathrm{mL}$ of $\mathrm{H}_{2}$ is produced over an electrolysis period of $1 \mathrm{~h}$ with a Faradaic efficiency of 97.6\% for $\mathrm{H}_{2}$ (Fig. S10-b). From equations (1) and (3) [10], we calculated the TOF for the catalyst as reaching a maximum of 676.6 moles of hydrogen per mole of catalyst per hour at an overpotential of $836.7 \mathrm{mV}$ (Eq. S3 and Table 2), where

Overpotential $=$ Applied potential $-\mathrm{E}(\mathrm{pH})=$ Applied potential- $(-0.059 \mathrm{pH})$

Table 2 Catalytic data of complexes $\mathbf{1}$ and $\mathbf{2}$ in aqueous buffer

\begin{tabular}{|l|l|l|l|l|}
\hline Components & Charge $(\mathrm{mC})^{\mathrm{a}}$ & TOF & $\begin{array}{l}\text { The amount of } \\
\mathrm{H}_{2}(\mathrm{~mL})^{\mathrm{b}}\end{array}$ & Faradaic efficiency $^{\mathrm{c}}$ \\
\hline Complex 1 & 817 & 676.6 & 0.636 & $97.6 \%$ \\
\hline Complex 2 & 675 & 554.0 & 0.347 & $97 \%$ \\
\hline
\end{tabular}

a 2 min of electrolysis; ${ }^{\mathrm{b}}$ electrolysis for $1 \mathrm{~h}$ under $-1.45 \mathrm{~V}$ versus $\mathrm{Ag} / \mathrm{AgCl} ;{ }^{\mathrm{c}}$ over an electrolysis period of $1 \mathrm{~h}$.

Different from complex 1, when the applied potential is $-1.45 \mathrm{~V}$ versus $\mathrm{Ag} / \mathrm{AgCl}$, the maximum charge reaches $675 \mathrm{mC}$ during $2 \mathrm{~min}$ of electrolysis with complex 2 
(Fig. 7c). From Fig. S11a, $\sim 0.347 \mathrm{~mL}$ of $\mathrm{H}_{2}$ is produced over an electrolysis period of $1 \mathrm{~h}$ with a Faradaic efficiency of $97 \%$ for $\mathrm{H}_{2}$ (Fig. S11-b). From Equations (1) and (3), we also calculate the TOF for the catalyst as reaching a maximum of 554.0 moles of hydrogen per mole of catalyst per hour at an overpotential of $836.7 \mathrm{mV}$ (Eq. S4 and Table 2).

Similar to that in organic media, complex $\mathbf{1}$ also shows higher efficiency for hydrogen production than complex $\mathbf{2}$ in aqueous media. From a $72 \mathrm{~h}$ controlled-potential electrolysis of a $0.25 \mathrm{M}$ buffer solution ( $\mathrm{pH} 7.0$ ) in the presence of complex $\mathbf{1}$ or $\mathbf{2}$, we also found that catalyst $\mathbf{1}$ is a more active species than $\mathbf{2}$. As shown in Fig. S12a, a total of $777 \mathrm{C}$ is accumulated during the electrolysis catalyzed by complex $\mathbf{1}$, whilst in the presence of complex 2 , only $450 \mathrm{C}$ is accumulated during a 72 h electrolysis (Fig. S12b).

\section{Conclusions}

In this paper, we have described two new iron(III) complexes that are easily obtained from the reactions of simple iron salts with amine-bis(phenolate) ligands. They have been characterized by physico-chemical and spectroscopic methods. Electrochemical studies show that the iron complexes with more positive $\mathrm{Fe}^{\mathrm{III} / \mathrm{II}}$ redox potentials show a lower activity for hydrogen generation. The results are consistent with a decrease in the catalytic activity when a weakly activating electron donating group is present at the phenol para-position of the ligand. Our ongoing efforts are focused on modifying the Schiff base ligand to give related water-soluble complexes 
for further functional studies, with an emphasis on chemistry relevant to sustainable energy cycles.

\section{Supporting information}

CCDC 1436090 and 1436091 contain the supplementary crystallographic data for this complexes $\mathbf{1}$ and $\mathbf{2}$, and these data can be obtained free of charge via http://www.ccdc.cam.ac.uk/conts/retrieving.html

\section{Acknowledgements}

This work was supported by the National Science Foundation of China (No. 20971045, 21271073).

\section{References}

[1] M. G. Walter, E. L. Warren, J. R. McKone, S. W. Boettcher, Q. X. Mi, E. A. Santori, N. S. Lewis, Chem. Rev. 110 (2010) 6446-6473.

[2] H. M. Chen, C. K. Chen, R. S. Liu, L. Zhang, J. J. Zhang, D. P. Wilkinson, Chem. Soc. Rev. 41 (2012) 5654-5671.

[3] J. W. Tye, M. B. Hall, M. Y. Darensbourg, Proc. Nat. Acad. Sci. USA. 102 (2005) 16911-16912.

[4] P. M. Vignais, B. Billoud, Chem. Rev. 107 (2007) 4206-4272.

[5] T. Goris, A. F. Wait, M. Saggu, J. Fritsch, N. Heidary, M. Stein, I. Zebger, F. Lendzian, F. A. Armstrong, B. Friedrich, O. Lenz, Nat. Chem. Biol. 7 (2011) 310-318.

[6] K. A. Vincent, A. Parkin, F. A. Armstrong, Chem. Rev. 107 (2007) 4366-4413. 
[7] B. J. Fisher, R. Eisenberg, J. Am. Chem. Soc. 102 (1980) 7361-7363.

[8] M. L. Helm, M. P. Stewart, R. M. Bullock, M. R. DuBois, D. L. DuBois, Science 333 (2011) 863-866.

[9] J. P. Cao, T. Fang, L. Z. Fu, L. L. Zhou, S. Z. Zhan, Int. J. Hydrogen Energy 39 (2014) 10980-10986.

[10] L. Chen, G. Chen, C. Leung, S. Yiu, C. Ko, E. Anxolabéhère-Mallart, M. Robert, T. Lau, ACS Catal. 5 (2015) 356-364.

[11] Y. Sun, J. P. Bigi, N. A. Piro, M. L. Tang, J. R. Long, C. J. Chang, J. Am. Chem. Soc. 133 (2011) 9212-9215.

[12] W. M. Singh, T. Baine, S. Kudo, S. Tian, X. A. N. Ma, H. Zhou, N. J. DeYonker, T. C. Pham, J. C. Bollinger, G. L. Baker, B. Yan, C. E. Webster, X. Zhao, Angew. Chem. Int. Ed. 51 (2012) 5941-5944.

[13] B. D. Stubbert, J. C. Peters, H. B. Gray, J. Am. Chem. Soc. 133 (2011) 18070-18073.

[14] L. Z. Fu, L. L. Zhou, L. Z. Tang, Y. X. Zhang, S. Z. Zhan, J. Power Sources 280 (2015) 453-458.

[15] T. B. Rauchfuss, Acc. Chem. Res. 48 (2015) 2107-2116.

[16] M. E. Carroll, B. E. Barton, T. B. Rauchfuss, P. J. Carroll, J. Am. Chem. Soc. 134 (2012) 18843-18852.

[17] F. Quentel, G. Passard, F. Gloaguen, Energy Environ. Sci. 5 (2012) 7757-7761.

[18] A. D. Nguyen, M. D. Rail, M. Shanmugam, J. C. Fettinger, L. A. Berben, Inorg. Chem. 52 (2013) 12847-12854. 
[19] L. Z. Fu, T. Fang, L. L. Zhou, S. Z. Zhan, RSC. Adv. 4 (2014) 53674-53680.

[20] J. P. Cao, T. Fang, L. Z. Fu, L. L. Zhou, S. Z. Zhan, Int. J. Hydrogen Energy 39 (2014) 13972-13978.

[21] P. Zhang, M. Wang, Y. Yang, T. Yao, L. Sun, Angew. Chem. Int. Ed. 53 (2014) 13803-13807.

[22] L. L. Zhou, T. Fang, J. P. Cao, Z. Zhu, X. Su, S. Z. Zhan, J. Power Sources 273 (2015) 298-304.

[23] T. Fang, L. Z. Fu, L. L. Zhou, S. Z. Zhan, Electrochim. Acta 161 (2015) 388-394.

[24] H. I. Karunadasa, C. J. Chang, J. R. Long, Nature 464 (2010) 1329-1333.

[25] J. P. Cao, T. Fang, L. L. Zhou, L. Z. Fu, S. Z. Zhan, J. Power Sources 272 (2014) $169-175$

[26] J. P. Cao, T. Fang, L. L. Zhou, L. Z. Fu, S. Z. Zhan, Electrochim. Acta 147 (2014) 129-135.

[27] J. Lloret-Fillol, Z. Codol, I. Garcia-Bosch, L. Gmez, J. J. Pla, M. Costas, Nat. Chem. 3 (2011) 807-813.

[28] M. K. Coggins, M. Zhang, A. K. Vannucci, C. J. Dares, T. J. Meyer, J. Am. Chem. Soc. 136 (2014) 5531-5534.

[29] Z. Q. Wang, Z. C. Wang, S. Z. Zhan, J. S. Ye, App. Cata. A: General 490 (2015) $128-132$.

[30] G. P. Connor, K. J. Mayer, C. S. Tribble, W. R. McNamara, Inorg. Chem. 53 (2014) 5408-5410.

[31] G. M. Sheldrick, SADABS, program for empirical absorption correction of area 
detector data. University of Götingen, Götingen, Germany, 1996.

[32]. G. M. Sheldrick, SHELXS 97, program for crystal structure refinement. University of Götingen, Götingen, Germany, (1997)

[33] B.P. Gaber, V. Miskowski, T.G. Spiro, J. Am. Chem. Soc. 96 (1974) 6868-6873.

[34] A. Neves, M.A. deBrito, I. Vencato, V. Drago, K. Griesar, W. Haase, Inorg. Chem. 35 (1996) 2360-2368.

[35] G. P. Connor, K. J. Mayer, C. S. Tribble, W. R. McNamara, Inorg. Chem. 53 (2014) 5408-5410.

[36] G. A. N. Felton, R. S. Glass, D. L. Lichtenberger, D. H. Evans, Inorg. Chem. 45 (2006) 9181-9184.

[37] Z. Codol, I. Garcia-Bosch, F. Acuna-Pares, I. Prat, J. M. Luis, M. Costas, J. Lloret-Fillol, Chem. Eur. J. 19 (2013) 8042-8047. 

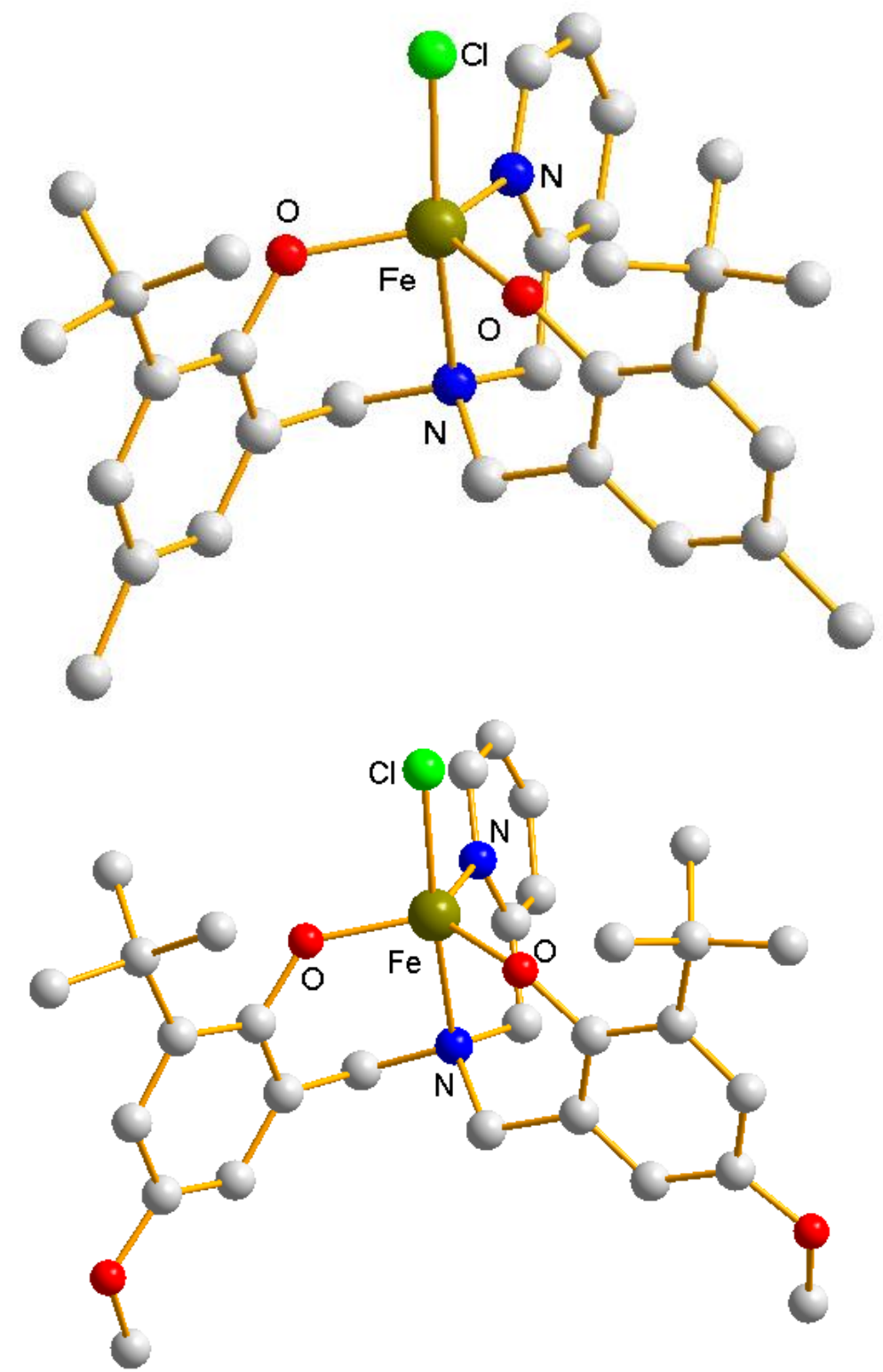

Fig. 1. Molecular structures of complexes 1 (top) and 2 (down) 

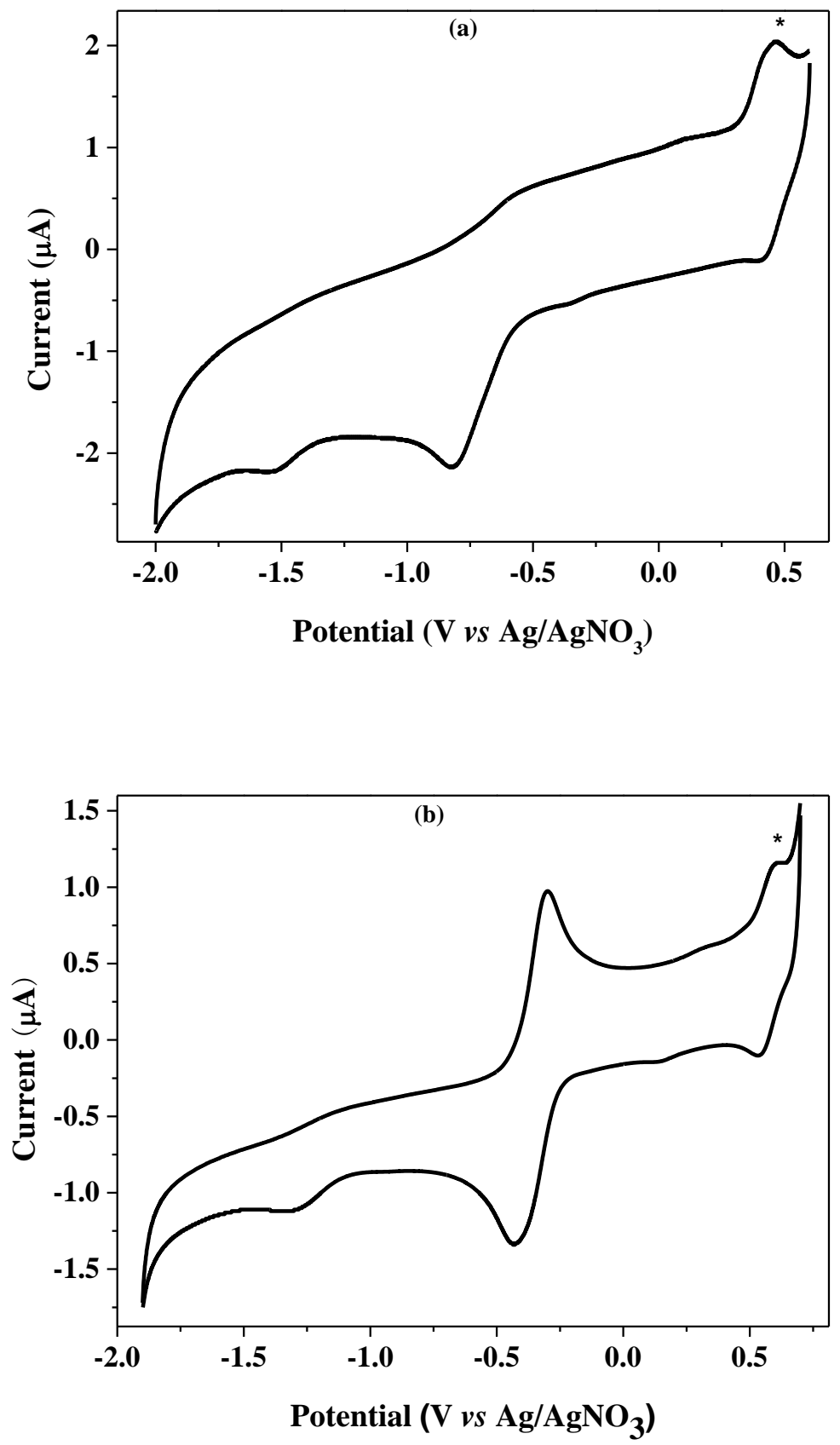

Fig. 2. $\mathrm{CVs}$ of $4.3 \mu \mathrm{M}$ complexes $\mathbf{1}$ (a) and 2 (b) in $0.10 \mathrm{M}\left[\mathrm{n}-\mathrm{Bu}_{4} \mathrm{~N}\right] \mathrm{ClO}_{4}$ solution at a glassy carbon electrode and a scan rate of $100 \mathrm{mV} / \mathrm{s}$. Fc internal standard (*). 

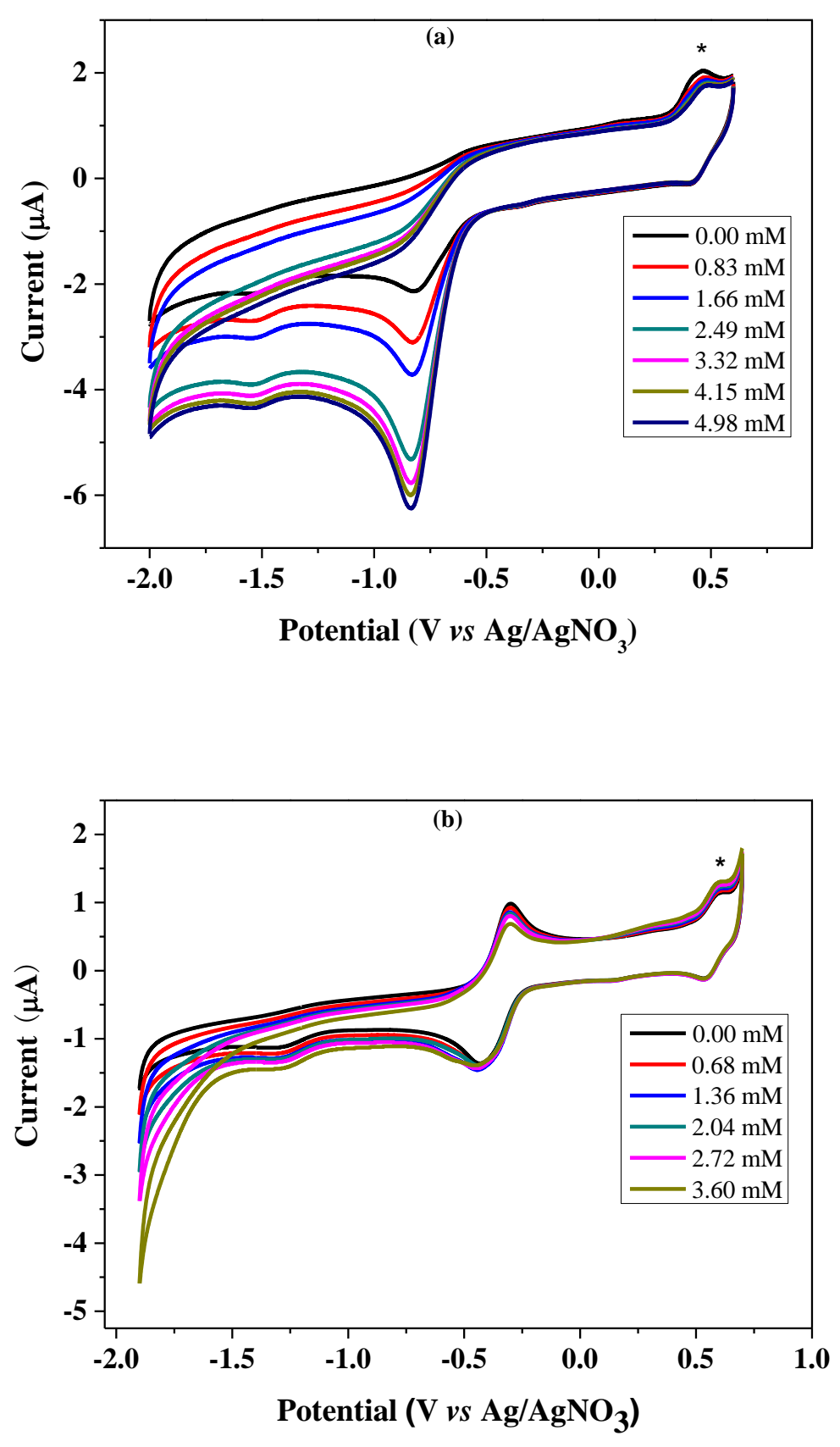

Fig. 3. (a) CVs of a $4.5 \mu \mathrm{M}$ solution of complex $\mathbf{1}$, with varying concentrations of acetic acid in DMF. (b) CVs of a $4.3 \mu \mathrm{M}$ solution of complex 2, with varying concentrations of acetic acid in DMF. Conditions: Room temperature, $0.10 \mathrm{M}$ $\left[\mathrm{n}-\mathrm{Bu}_{4} \mathrm{~N}\right] \mathrm{ClO}_{4}$ as supporting electrolyte, $100 \mathrm{mV} / \mathrm{s}$ (scan rate), glassy carbon working electrode (1 mm diameter), Pt counter electrode, $\mathrm{Ag} / \mathrm{AgNO}_{3}$ reference electrode, $\mathrm{Fc}$ internal standard $(*)$. 

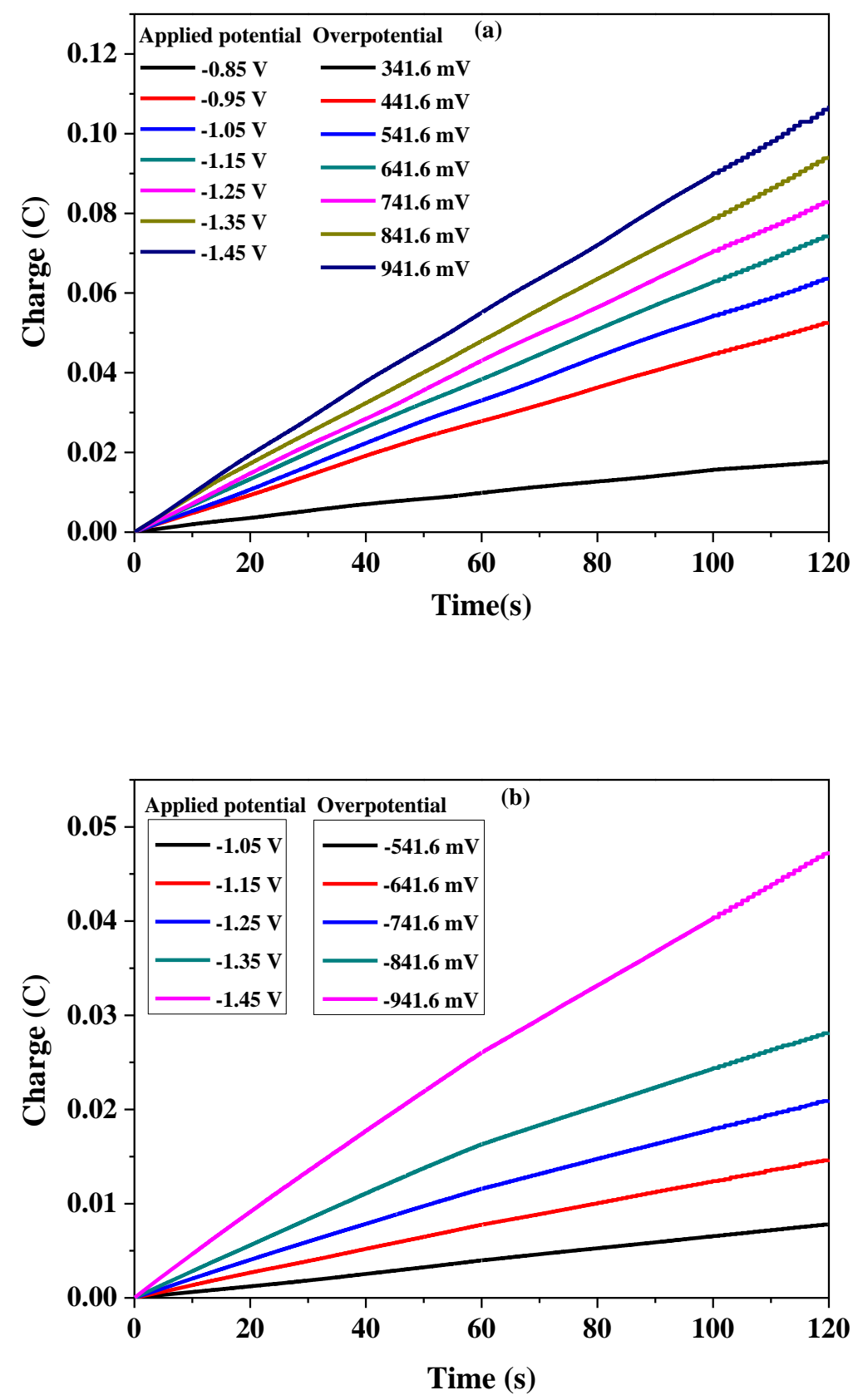


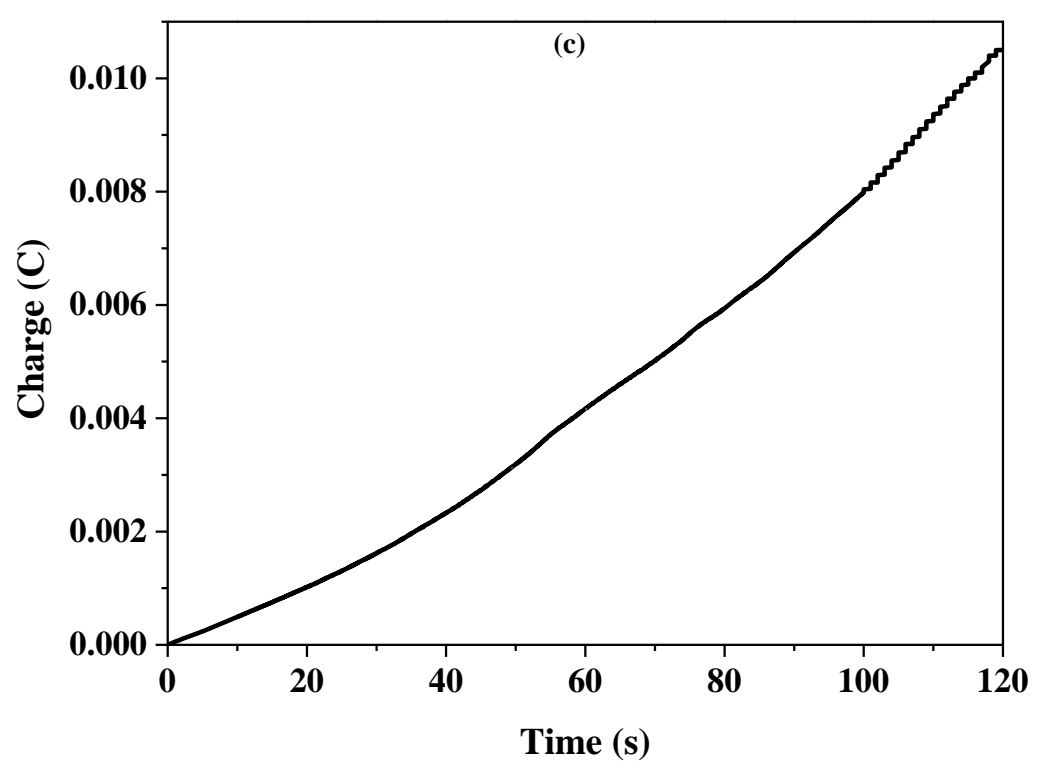

Fig. 4. (a) Charge buildup versus time from electrolysis of a $0.18 \mu \mathrm{M}$ complex 1 in DMF $\left(0.10 \mathrm{M}\left[\mathrm{n}-\mathrm{Bu}_{4} \mathrm{~N}\right] \mathrm{ClO}_{4}\right)$ under various applied potentials. All data have been deducted blank. (b) Charge buildup versus time from electrolysis of a $0.17 \mu \mathrm{M}$ complex 2 in DMF $\left(0.10 \mathrm{M}\left[\mathrm{n}-\mathrm{Bu}_{4} \mathrm{~N}\right] \mathrm{ClO}_{4}\right)$ under various applied potentials. All data have been deducted blank. (c) Charge buildup versus time from electrolysis of a $0.10 \mathrm{M}\left[\mathrm{n}-\mathrm{Bu}_{4} \mathrm{~N}\right] \mathrm{ClO}_{4}$ solution in $\mathrm{DMF}$ under $-1.45 \mathrm{~V}$ versus $\mathrm{Ag} / \mathrm{AgNO}_{3}$. 

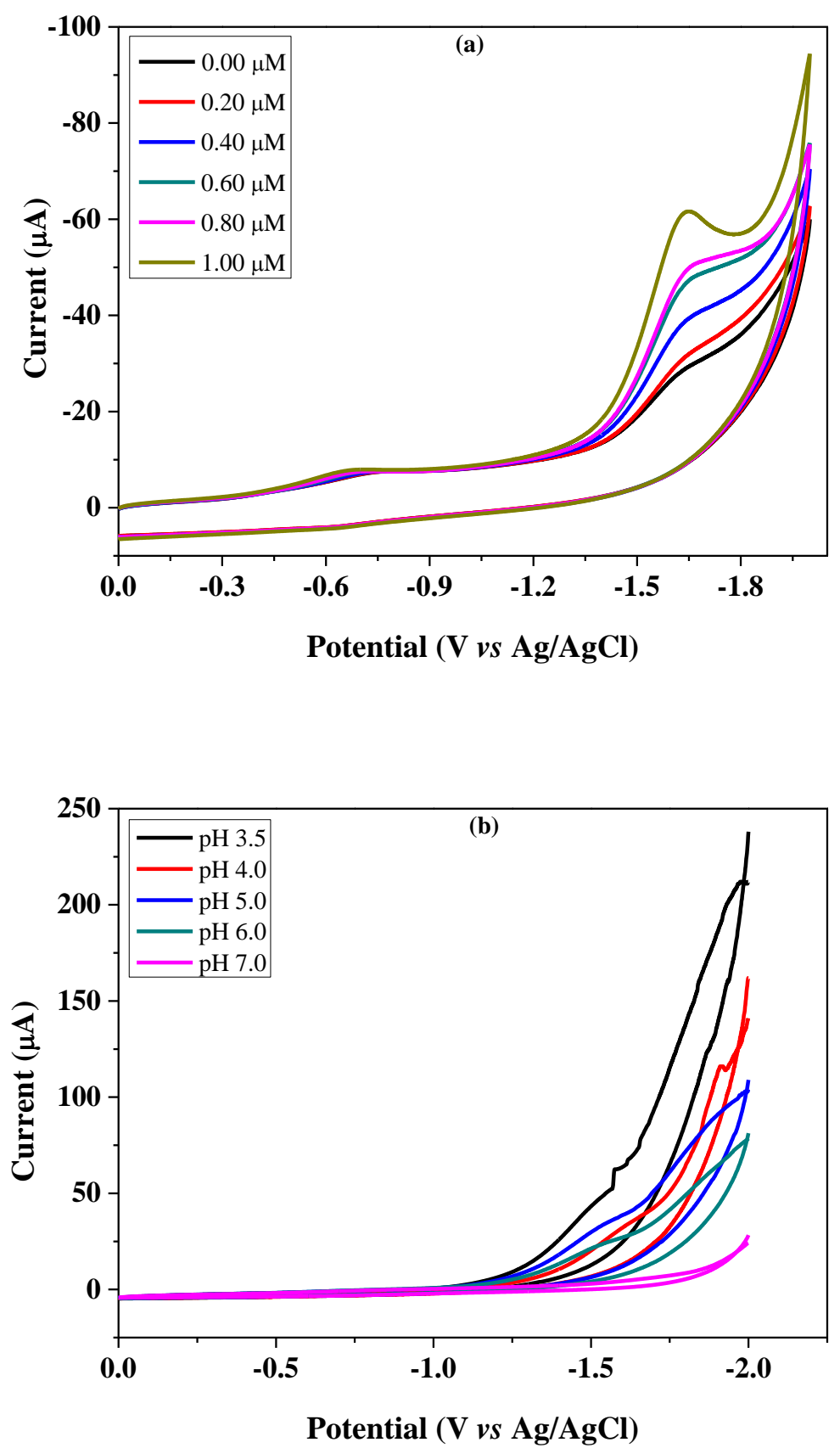

Fig. 5. (a) CVs of complex $\mathrm{I}$ in different concentration. (b) CVs of $1.30 \mu \mathrm{M}$ complex 1, showing the variation in catalytic current with $\mathrm{pH}$ (scan rate: $100 \mathrm{mV} / \mathrm{s}$ ). Conditions: $0.25 \mathrm{M}$ phosphate buffered solution at $\mathrm{pH} 7.0$, glassy carbon working electrode (1 mm diameter), $\mathrm{Pt}$ wire counter electrode, $\mathrm{Ag} / \mathrm{AgCl}$ reference electrode. 

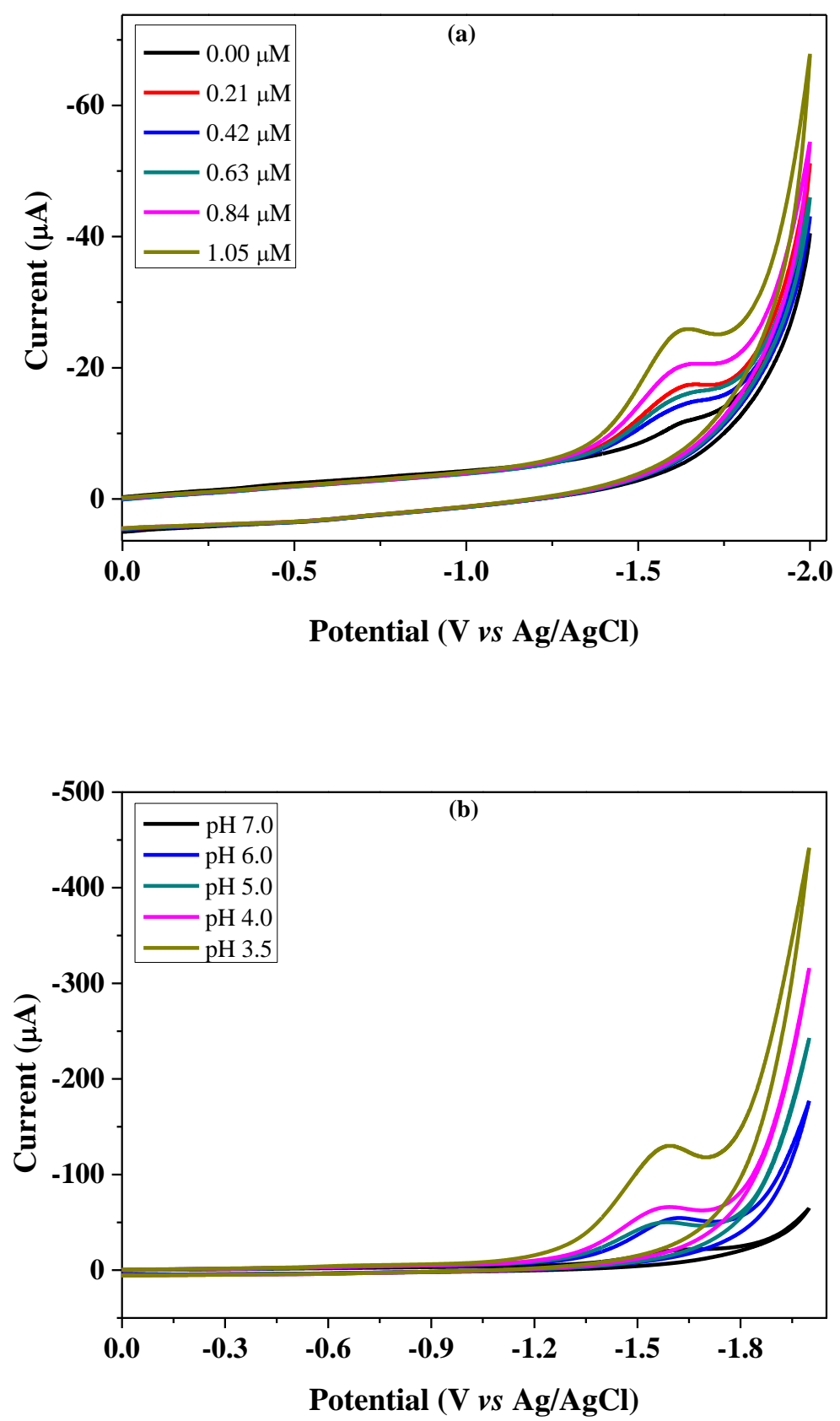

Fig. 6. (a) CVs of complex 2 in different concentration. (b) CVs of $1.30 \mu \mathrm{M}$ complex 2, showing the variation in catalytic current with $\mathrm{pH}$ (scan rate: $100 \mathrm{mV} / \mathrm{s}$ ). Conditions: $0.25 \mathrm{M}$ phosphate buffered solution at $\mathrm{pH}$ 7.0, glassy carbon working electrode (1 mm diameter), $\mathrm{Pt}$ wire counter electrode, $\mathrm{Ag} / \mathrm{AgCl}$ reference electrode. 

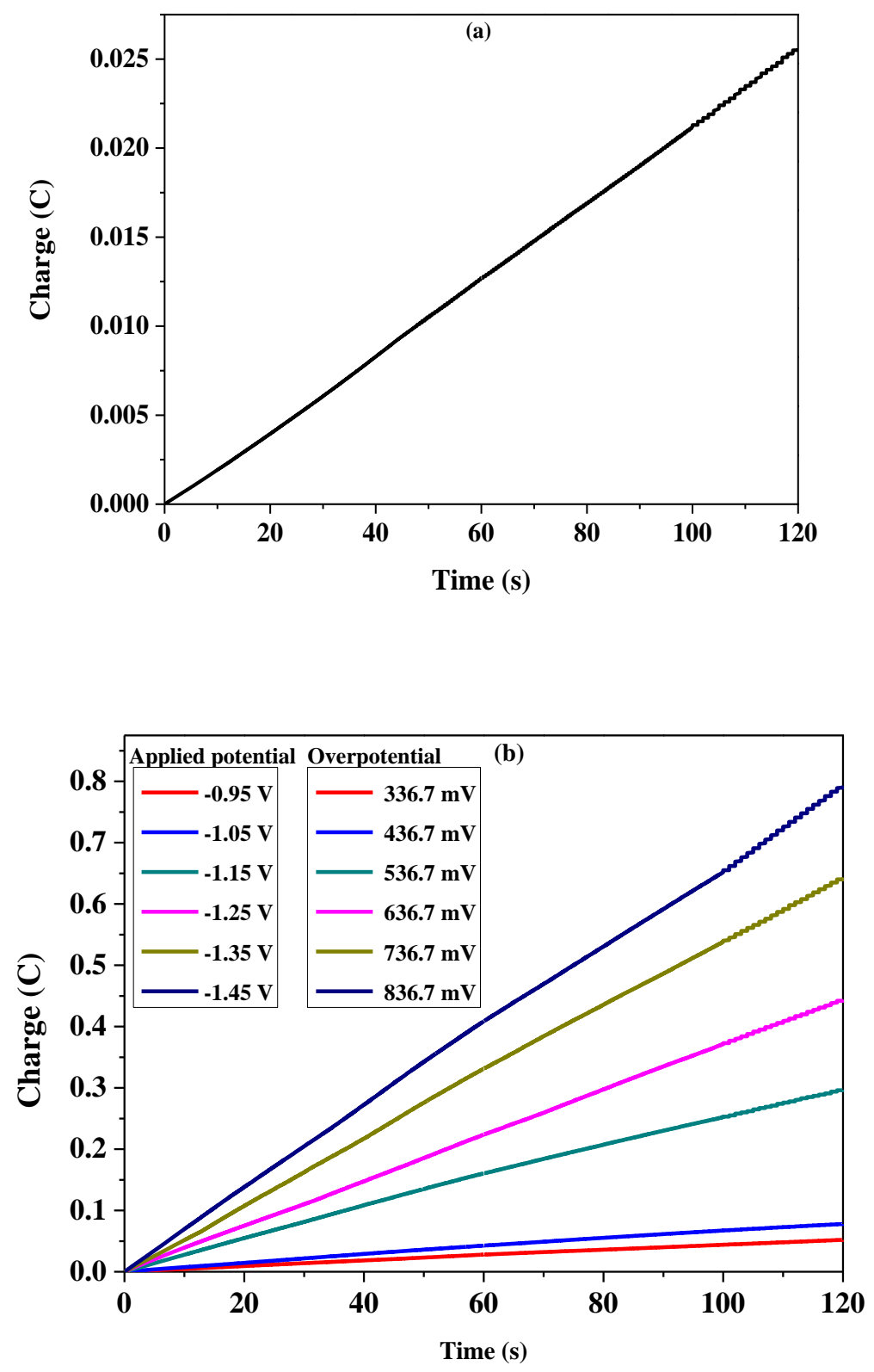


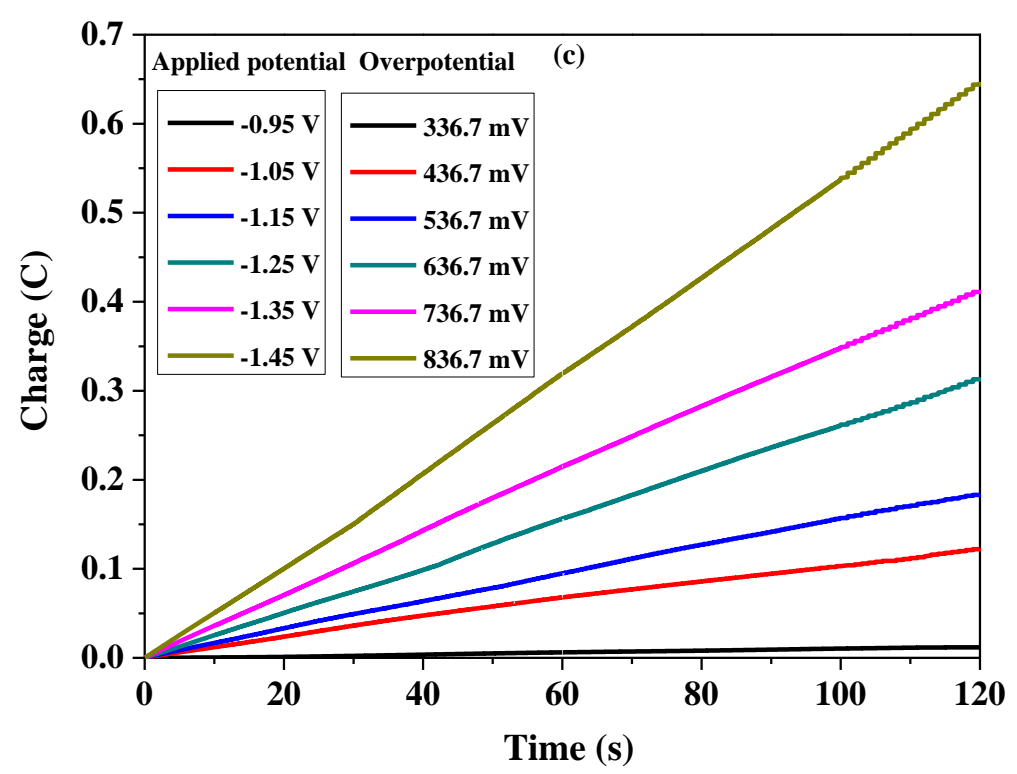

Fig. 7. (a) Charge buildup versus time from electrolysis of $0.25 \mathrm{M}$ aqueous buffer (pH 7.0). (b) Charge buildup versus time from electrolysis of $0.182 \mu \mathrm{M}$ complex 1 in a $0.25 \mathrm{M}$ buffer ( $\mathrm{pH} 7.0)$ under a series of applied potentials, all data have been deducted blank. (c) Charge buildup versus time from electrolysis of $0.182 \mu \mathrm{M}$ complex 2 in a $0.25 \mathrm{M}$ buffer ( $\mathrm{pH}$ 7.0) under a series of applied potentials, all data have been deducted blank. 
${ }^{*}$ Graphical Abstract

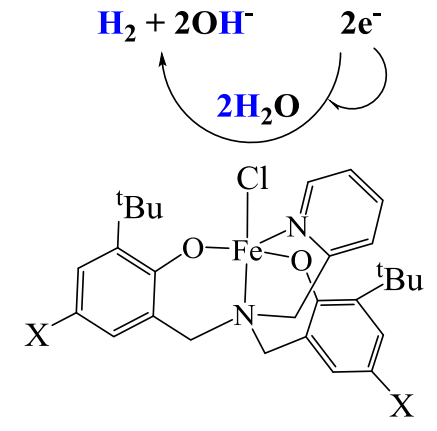

$(\mathrm{X}=\mathrm{Me}, \mathrm{LFe}(\mathrm{Cl}) \mathbf{1}$;

$\mathrm{X}=\mathrm{OMe}, \mathrm{L}^{\prime} \mathrm{Fe}(\mathrm{Cl})$ 2) 